\title{
Approaches to geomarketing via office locations serving individuals and legal entities of a commercial bank
}

\author{
Ruslan A. Dolzhenko \\ Professor, Department of Labor Economics and Personnel Management \\ Ural State University of Economics; \\ Associate Professor, Department of Personnel Management and Socio-Economic Relations \\ Altai State University \\ Address: 62/45, 8 Marta / Narodnoy Voli Street, Ekaterinburg, 620144, Russian Federation \\ E-mail: snurk17@gmail.com
}

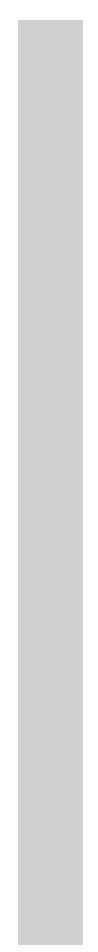

\begin{abstract}
In this article we examine the possibility of using geomarketing as a tool for modeling the spatial location of a bank's offices serving individuals and legal entities. Geomarketing is a marketing concept of modern production management based on geo-information technologies which involves the use of spatially localized information to support decision-making. This concept is particularly timely for commercial banks which present their services to customers in an extensive network of service offices, because for the majority of banking services the determining factor in the consumer's choice of bank for a given service will be the convenience of the location of its office.

The article describes a sequence of typical steps in geomarketing simulations and makes recommendations for the implementation of each selected stage. Methodical approaches to the implementation of geomarketing modeling for an optimal network of the bank's service offices are highlighted. Problems in the organization of the network of service offices of the bank which can be solved with the help of geomarketing design are studied. Recommendations are presented for evaluating the capacity of a commercial bank's office service network depending on their specialization in serving individuals or legal entities. An algorithm is presented for calculating the service office network capacity for individuals together with respective formulas. An approach to evaluating the capacity of the office network servicing legal entities is described. Recommendations are offered for implementing the evaluation of planned location of offices servicing the bank's clients, as well as for determining the habitats of their preferred location to facilitate the most effective coverage of the local market while taking into account the return on investment in offices.
\end{abstract}

Key words: bank, sales office, geomarketing, geomarketing modeling, rational location of sales offices, placement rating.

Citation: Dolzhenko R.A. (2017) Approaches to geomarketing via office locations serving individuals and legal entities of a commercial bank. Business Informatics, no. 3 (41), pp. 41-55.

DOI: 10.17323/1998-0663.2017.3.41.55. 


\section{Introduction}

U nder conditions of a developing market economy and increasing competition, domestic companies have been compelled to review their approach to determining where to locate their offices. Points of sale and service offices must be placed not in some accidentally arrived at locations but with precision, where the client flow and convenience for visitors will be optimal. Companies must evaluate not only current possibilities for rational location of offices but also the dynamics of change over the coming years. Success will accompany only those organizations servicing clients which take into account the geographic location of their offices and customers. This is why it is highly relevant to do research using modeling for rational placement of a company's offices in the markets where it has a presence.

The majority of organizations take a superficial approach to using the potential of modeling their geographic representation in territorial markets and, as a rule, use data from various geographic information systems (GIS), with the help of which they identify and visualize the location of offices on a map of the local market. But displaying the organization's points of presence on the city map does not by itself give any supplemental information which could qualitatively improve the effectiveness of the network's operations. You have to carry out detailed research of local markets, identify data about customers, highlight the factors which can influence their travel around the city. This is why it is relevant to use in business geo-information technologies and, in particular, geomarketing. This field is extremely important for commercial banks, especially those which have an extensive network of offices.

In practice, we see that a bank's success with customers is determined more and more by the intensity of the company's advertising and by successful location of sales offices. Of course, the innovative culture of the financial organi- zation is also an important factor, but its significance is not so great. For example, the majority of domestic customers - individuals - are not acquainted with the possibilities of mobile banking. For such consumers of banking services, the determining factor when choosing a bank to service accounts will be convenient locations of its offices [1]. That is precisely why geomarketing modeling of the network of sales offices of a credit organization is extremely topical at present. This study is devoted to the given subject.

Before we review the possibilities for network modeling of office locations in a commercial bank, we will define the basic concepts of geomarketing.

\section{The essence of geomarketing and the possibilities of using it in practice within a credit organization}

From the structure of the word "geomarketing", one can already conclude that it arose at the intersection of two sciences: marketing and geo-computer science. It is the field of marketing analysis using methods of geocomputer science [2]. Thus, geomarketing was founded on the use of GIS when analyzing a market and making decisions about the activity of the organization within it. There are two points of view on the definition of the given concept: one broad, the other narrow. In the first case, geomarketing can be defined as an approach to collection of data located in space when making marketing decisions. This approach is widespread in Europe. For example, in France it is supported by the National Council on Geographic Information (Conseil national de l'information géographique). The narrow interpretation of the "geomarketing" concept is more widespread in the USA, where it is taken to mean a computer system of programs, processes and materials which allow you to collect, manage, manipulate, analyze, model and select spatial data for complex management of a marketing system in the organiza- 
tion. The given approach is used by the Federal Inter-Agency Committee for Coordination of Digital Cartography.

In Russian language scientific works, the narrow approach is more common. For example, in an article by I.G. Zhurkin and V.Y. Tsvetkov we find the following definition of geomarketing: it is the "process of planning, decisionmaking, price formation, promotion and sale of ideas, goods and services (including information and political services) by means of exchange satisfying the objective of separate individuals and organizations with the help of geo-information technologies" [3].

Use of geomarketing in business practice enables the organization to get answers to three key questions:

$\downarrow$ How many sales offices does the organization need to efficiently serve its current and future client base?

$\downarrow$ How should these offices be configured on the map of the city in order to take in the biggest client flow? $\downarrow$ How should the offices be situated relative to one another for maximum financial result?

Essentially, use of geomarketing when modeling the rational location of the organizations's network of points of presence on the local market enables the firm to create a model of the most effective location of offices on the city map, to compare that with the existing network of offices and to take actions to improve the network till it reaches the target state.

The technology of geomarketing modeling of the organization's network of offices is applied, as a rule, in three stages which are represented schematically in Figure 1.

Evaluation of the potential of sales office locations on the local market has key importance in geomarketing modeling.

Geomarketing evaluation is the method of assessing the location of an office with the help of which we determine the likelihood of high client flow in the bank's sales office. The special feature of this method is that for each cri-

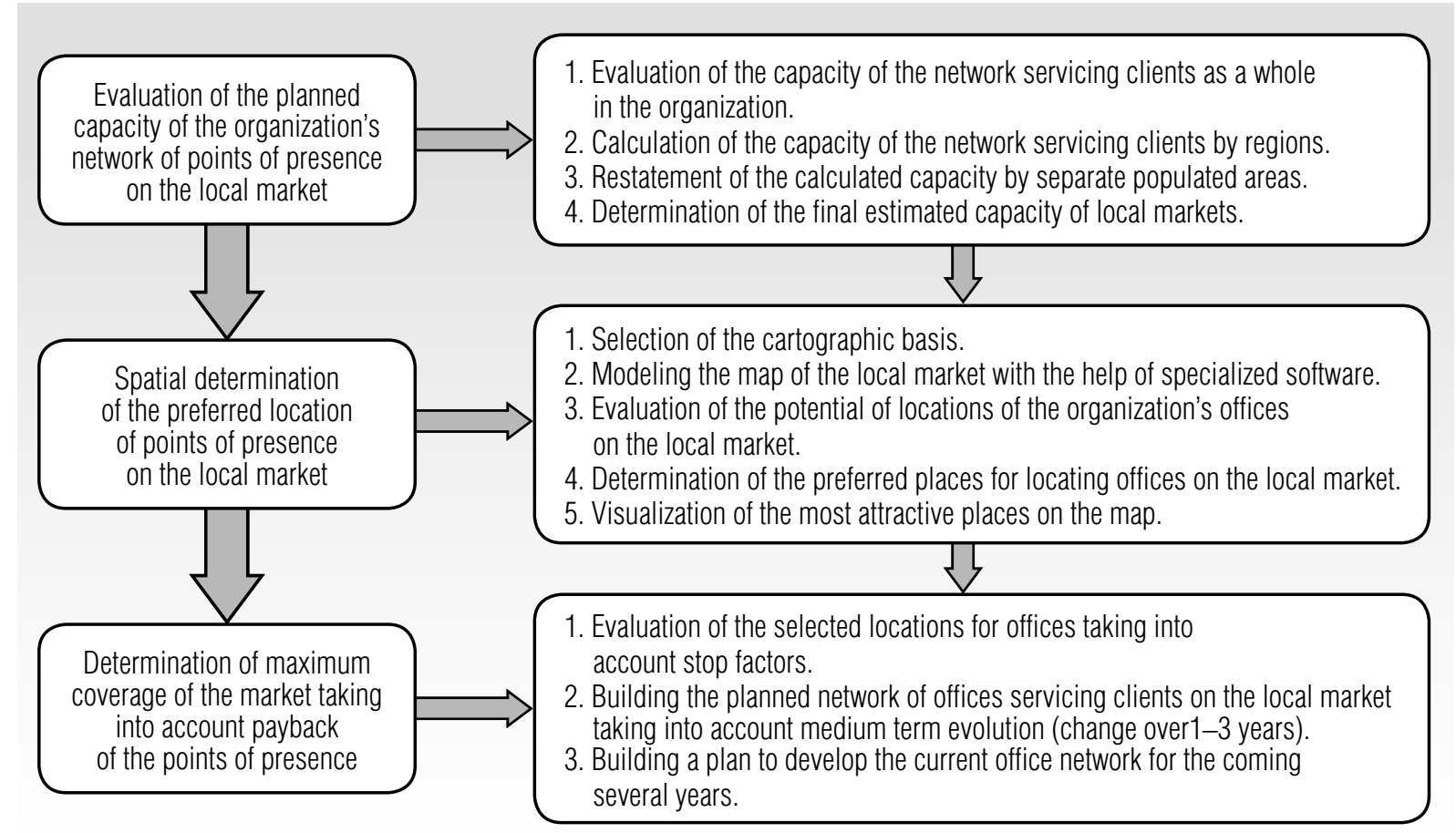

Fig. 1. Stages of geomarketing modeling of rational locations for the organization's office network 
terion in the system of evaluating the location a specific score is assigned.

Experience shows that the effectiveness of a geomarketing evaluation largely depends on the extent to which the following three groups of factors are taken into account when modeling.

1. Correspondence to the basic criteria of the local market. In the modeling process, one must take into account the density of population. In addition, one must direct attention to the sources of additional flow of clients such as buildings and places attracting the interest of the population, for example, metro stations, restaurants, entertainment centers, etc.

2. Correspondence to the criteria of location of points of sale. In particular, one has to take into account the location of public transport stops, the transport lines around the planned point of sales (the greater the number of such lines, the higher the evaluation of the location will be). An important criterion when modeling is the density of pedestrian flows in front of the office. A high level shows that in the given place there is no obstacle to pedestrians getting around between parts of the local market. For example, the presence of a pedestrian crossing (whether underground or above ground) increases the flow of people. Moreover, it allows clients to freely walk up to the office from across the street, which is important especially when there is dense automobile traffic.

3. The premises of sales offices, independently of their location on the local market, must correspond to certain criteria: it is desirable for the location of a sales point to be on the ground floor; one must take into account the presence of windows on the facade of the building; the most desirable location of the premises is on the first line of buildings; and, finally, if there is no possibility to arrange a separate entrance, that can significantly lower the quality of the premises.

Such are the general factors connected with geomarketing modeling. There is no doubt about the prospects for its use in practice within domestic organizations, especially for those which sell products and services to the population [4]. Further on we will review possibilities for using geomarketing tools applicable to a network of sales offices of a commercial bank. We will note that the possibilities for use of this technology for credit organizations are being actively studied by foreign and domestic researchers. Place as an element of the marketing mix is attracting the attention of many researchers. Therefore, the given field of research applicable to retail stores was studied for a long time, and as a result a large number of scientific works accumulated in this field. But what is the situation with respect to research into geomarketing modeling in the field of optimization of the branch network of bank offices?

The first publication on the given topic in foreign scientific literature dates back to 1978 [5]. It is indicative that it reviewed the possibilities of computer-aided mapping (CAM) for building the bank's branch network. On the basis of research into the branch network of a major American bank, the authors of the work proposed an approach to making marketing decisions with help from the mapping of geographic space and determination of the potential locations for branches of the financial organization. Despite the fact that almost 40 years have gone by since its publication, the relevance of the given subject has not declined.

Researchers in the given field offer various approaches to modeling the behavior of consumers, on the basis of which, in their opinion, one can take decisions about the location of offices in the space of populated areas. Approaches to modeling the behavior of consumers were analyzed in detail in the work of S.G. Kiselgof [6]. In this study, it was shown that the behavior of consumers, including consumers of bank services, can be determined by several key factors which researchers use as their basis. For example, they include the level 
of education of the population, the number of organizations on the territory, the size of offices, the distance from the nearest commercial center, the location of the office with respect to the daily itinerary of consumers, and others [7].

All of these factors to a greater or lesser degree have their impact on the attractiveness of bank branches. Consequently, by doing modeling, one can determine the expected number of clients in the bank's points of presence and use the given information for taking decisions about the fate of offices in the future. In particular, the given approach is used in the work of L.D. Huff [8].

More and more often, foreign researchers agree that increasing the speed of moving consumers around the city develops further the importance of such an indicator as "client flow of consumers". Their preferences can be ignored in conditions when choice of the place of service is determined by convenience of location, speed of service, as well as throughput capacity of the office [9-12]. It is noteworthy that in domestic banking practice they began to pay attention to this only in the last decade. Thus, Sberbank, as the provider of management innovations in the banking sector, for purposes of resolving the problem of client flows, set for itself the task in 2012 to reduce the time of serving clients in its offices on average to 10 minutes (the Sberbank project "Ocheredey. Net"). For consumers, what counts more now is not the distance between points in the city but the speed with which it can be overcome.

In the domestic scientific milieu, the given topic has been examined in a number of works by F.T. Aleskerov and co-authors [13-15], from the position of the possibilities of mathematically modeling the rational location of bank offices. For example, approaches to modeling behavior in various circumstances are described in the work of S.G. Kiselgof and F.T. Aleskerov [15]. In works by F.T. Aleskerov and V.Y. Belousova [13, 14], an analysis was made of preferred location territories for the bank at the macro-level. In particular, they determined the most attractive regions of the RF for opening new offices.

This work is a continuation of the scientific work of our colleagues in the given field. The accent is placed on practical aspects of using the technology of geomarketing which can be used by any credit organization when expanding or transforming its branch network.

\section{Methodological approaches to geomarketing modeling of a bank's network of sales offices}

The use of geomarketing in bank activity makes it possible to solve a number of essential methodological problems which credit organizations face. The key problems and tools for solving them are presented in Table 1.

Geomarketing modeling of a bank's network of sales offices includes three main stages.

1. Determination of the capacity of the network of offices. At the given stage, one calculates the necessary number of work places for servicing the client base of the region for each year with a planning horizon of five years. The final result of this stage of geomarketing is an evaluation of the approximate number of offices. A macro-economic model for analysis of capacity will be described below.

2. Determination of the habitats of preferred office locations. The city is divided into local markets, each of which is characterized by the total capacity of sources of additional client flows and the geomarketing scoring system. The result of this stage is the determination of the assessment of locations by number of transactions and volume of sales in the bank's points of sale.

3. Determination of the most effective coverage of the local market taking into account payback of the sales office. Depending on the score, one determines the necessary through- 
Problems with organizing a network of bank sales offices and the tools for their solution with the help of geomarketing modeling

\begin{tabular}{c|c}
\hline Basic problems & Tools for solving them \\
\hline $\begin{array}{c}\text { No forecast for capacity of the network } \\
\begin{array}{c}\text { Non-rational selection of the location } \\
\text { of sales offices }\end{array}\end{array}$ & $\begin{array}{c}\text { Macro-model and model of coverage of the local market make it possible } \\
\text { to calculate the target capacity of the network for several years ahead }\end{array}$ \\
\hline $\begin{array}{c}\text { Non-rational selection of formats } \\
\text { and sizes of sales offices }\end{array}$ & $\begin{array}{c}\text { In the maps, one must consider only the most significant } \\
\text { geomarketing factors }\end{array}$ \\
\hline $\begin{array}{c}\text { In the model of coverage of the local market, one must take into account not } \\
\text { only large format sales offices but also basic formats. And the latter must } \\
\text { gradually be replaced (according to need) by self-service offices } \\
\text { devices and offices }\end{array}$ & $\begin{array}{c}\text { Model of office payback mathematically ties down the forecast of growth } \\
\text { of key business indicators to the evaluation score }\end{array}$ \\
\hline $\begin{array}{c}\text { Expert' evaluation of payback } \\
\text { of sales offices }\end{array}$ &
\end{tabular}

put capacity of the sales office for each zone of rational location. At the conclusion of this final stage of geomarketing, one can take decisions on opening/closing/reformatting/moving the bank's sales office.

Let us examine the content of these three stages in greater detail.

\section{Determination of the capacity of the office network (stage 1)}

This stage comprises three steps. First, it is necessary to calculate the capacity of the network of sales offices as a whole by RF subject (territorial subdivision). This can be done on the basis of macro-economic forecasts and the bank's target benchmarks. The next step is related to restating the calculated capacity from the level of the subject of the federation to the level of a city. It is determined proportionally to the number of the economically active members of the population in the city. Finally, at the last step the forecast capacity in the context of the city is distributed between local markets proportionately to the assessment score of the market and to current distribution of the load on existing sales offices. The target capacity of the local market is determined by its summary evaluation score, or it can be calculated by two indicators: the number of service offices (taking into account the priority of formats) and the total number of workers who are required according to norms for service of the forecast client base over the coming five years. The given target capacity can be redistributed between shares of the local market across segments, starting from the specifics of the current distribution of clients, as well as the tendencies of the city's future development.

Let us look at an example of the assessment of the capacity of a network of offices for servicing bank clients. Given that the model for calculation differs according to the specialization of the office (servicing individuals or legal entities), we will examine the approach to evaluating capacity for each of these areas.

The evaluation of the capacity of a bank's office network for servicing legal entities can be done starting from the target number of clients across regions and segments (large, medium, small, micro-business), speed of growth of the client base by segments and norms for the number of clients per sales manager and the number of clients per cashier. The algorithm for calculating the target capacity is given in Figure 2. 


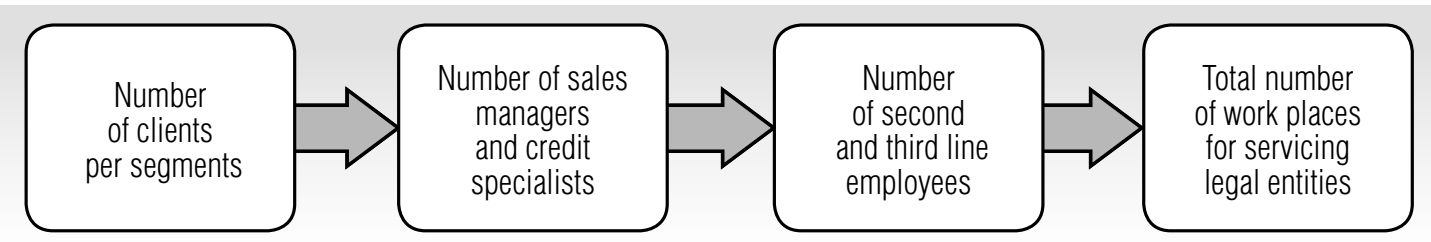

Fig. 2. Algorithm for calculating the capacity of a bank's office network servicing legal entities

The basic result of modeling is the calculation of the necessary capacities of the network by business segment taking into account change in the target shares of the market of the region. Moreover, for legal entities we calculate the target number of work places for workers of various categories (sales managers, credit inspectors, as well as second and third line staff such as cashiers and office managers).

The forecast number of a bank's legal entity clients can be determined by looking at the forecast rates of growth of the client base by segment (large, medium, small, micro-business). To calculate the forecast number of clients, we use the following formula:

$$
P N C=A N C \cdot(1+F G R),
$$

where $P N C$ is the predicted number of the bank customers from among legal entities;

$A N C$ is the actual number of the bank's clients from among legal entities;

$F G R$ is the forecast growth rate of the bank's client base.

Next it is necessary to calculate the forecast number of work places for cashiers, credit inspectors, sales managers by segment, as well as office managers. This number can be arrived at on the basis of the normative number of legal entity clients per sales manager, the normative number of credit contracts per credit inspector and the normative number of legal entity clients per cashier. As a rule, for each office there should be one office manager; for a large office, one may provide for deputy office manager positions.

Finally, the calculation of a target number of offices is made based on the forecast number of legal entity clients. In the given instance, the bank, given the accepted approaches to the format of offices (micro-, macro-, specialized, all-purpose), can decide precisely which formats for offices and in which quantities they are needed. For example, in Sberbank, there is an operative norm according to which one bank office should service from 700 to 3000 legal entity clients.

Thus, the macro-model described makes it possible to determine the rational state of a network of offices servicing legal entities, taking into account the planned rates of growth of the client base and the share of service represented by remote banking.

The evaluation of a bank's network of offices servicing individuals should be done using other principles. The main elements for calculating the macro-model are shown in Table 2.

The algorithm to calculate indicators for modeling the planned capacity of a bank's office network is shown in Figure 3.

Let us look at how within the model described we can calculate the basic indicators shown in Table 2 and Figure 3.

The calculation of the number of accounts per product in an $R F$ subject (constituent territory) per member of the economically active population (that portion of the country's population which already uses or wants to and potentially can use bank products and services; for purposes of modeling, one should place in this category individuals aged 18 to 65 ) is made on the basis of the current population numbers in the $R F$ subject, the portion of the population living in cities with 50,000 or more and the share of the population aged 18-65. 


\section{Basic elements for calculating a macro-model to evaluate the capacity of a bank's office network servicing individuals}

\begin{tabular}{c|c}
\hline Calculation indicator & Calculation algorithm \\
\hline $\begin{array}{c}\text { Total transaction volume by city } \\
\text { with a population greater than 50,000 }\end{array}$ & $\begin{array}{c}\text { Calculated on the basis of the target market share for deposits } \\
\text { and consumer credits, as well as forecast numbers of the economically } \\
\text { active part of the population in the RF subject (territorial unit) }\end{array}$ \\
\hline $\begin{array}{c}\text { Volume of transactions performed in an } \\
\text { office with physical presence of a cashier }\end{array}$ & $\begin{array}{c}\text { Calculated on the basis of the total transaction volume less the share } \\
\text { of remote banking services }\end{array}$ \\
\hline $\begin{array}{c}\text { Number of work places for cashiers in cities } \\
\text { with a population greater than 50,000 }\end{array}$ & $\begin{array}{c}\text { Calculated on the basis of the normative work time of one cashier work } \\
\text { place and forecast volume of transactions carried out in the office } \\
\text { with the physical presence of the cashier }\end{array}$ \\
\hline $\begin{array}{c}\text { Number of offices by format (large / basic) } \\
\text { by city with population greater than 50,000 }\end{array}$ & $\begin{array}{c}\text { Calculated on the basis of the developed typology of formats depending } \\
\text { on the number of cashier work places }\end{array}$ \\
\hline $\begin{array}{c}\text { Number of self-service devices (ATMs) } \\
\text { per city with population greater } \\
\text { than 50,000 }\end{array}$ & $\begin{array}{c}\text { Calculated on the basis of the normative load of self-service devices } \\
\text { by ATM and information-payment terminals given the forecast volume } \\
\text { of transactions and target share of remote banking services }\end{array}$ \\
\hline $\begin{array}{c}\text { Number of sales managers } \\
\text { for banking products }\end{array}$ & $\begin{array}{c}\text { Calculated on the basis of the number of sales and norms } \\
\text { of productivity of sales managers for banking products }\end{array}$ \\
\hline
\end{tabular}

Thus, the total number of accounts by product within the bounds of the $R F$ subject will be correlated with the number of the economically active population, as a result of which one can calculate the number of accounts of products per individual (the share of penetration of bank products within the given $R F$ subject). Goskomstat is a source of information for the calculation. The formula for calculating the given indicator looks as follows:

$$
N A=\frac{T N A}{P \cdot P U P \cdot P P},
$$

where $N A$ is the number of accounts of products per person;

$T N A$ is the total number of accounts by product;

$P$ is the population of the $R F$ subject;

$P U P$ is the proportion of urban population living in cities greater than 50,000 (this level of screening is used in order to exclude from the modeling small towns which according to the code book of rules "Urban development. Planning and residential construction of urban and rural communities" are considered in Russia to be towns with populations less than 50,000 and other types of populated areas);

$P P$ is population proportion of those aged $18-65$ (the age of potential bank clients).

The calculation of the target number for the bank's product accounts can be made on the basis of the forecast total number of accounts within the subject and the bank's target market share. Using data on the current population of cities with assumptions on growth/loss of population, one can build a forecast of the number of persons in the economically active population. In turn, the forecast total number of accounts by product within the $R F$ subject is calculated by year as the product of the number of economically active persons and the number of product accounts per person. Their correlation gives us the target number of bank products:

$$
T N A=\frac{E A P \cdot N A}{T M S},
$$

where TNA is the target number of accounts of bank products; 


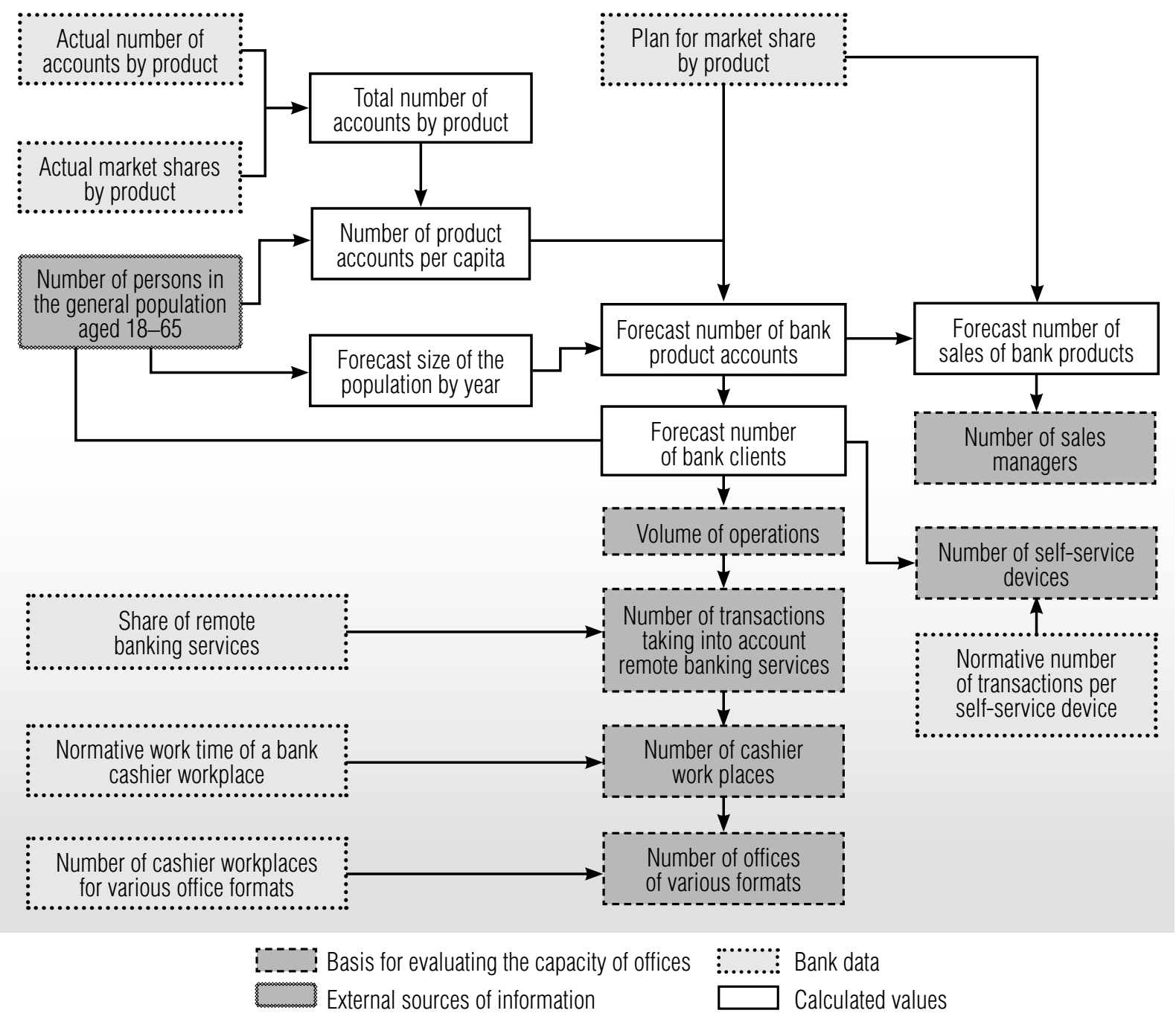

Fig. 3. Algorithm to calculate the capacity of the network servicing individuals

$E A P$ is the economically active population;

$N A$ is the number of product accounts per person;

TMS is the target market share of the bank for deposits within the $R F$ subject.

The calculation of the target number of bank clients is done by dividing the target number of bank deposit accounts by the number of bank deposit accounts per person. The total number of clients is calculated via the crossselling ratio, which is an input parameter of the model. The formula for calculating the given indicator looks as follows:
$T N C=\max \left[\frac{\left(\frac{T N A_{d}}{N A_{d}}+T N A_{h l}+T N A_{c c}\right)}{C S R}, \frac{T N A_{d}}{N A_{d}}\right]$

where $T N C$ is the target number of bank clients;

$T N A_{d}$ is the target number of deposit accounts;

$N A_{d}$ is the number of deposit accounts per person;

$T N A_{h l}$ is the target number of housing loan accounts; 
$T N A_{c c}$ is the target number of customer credit accounts;

CSR is the cross-selling ratio.

The calculation of the target number of work places for cashiers is made on the basis of the annual operating time fund per work place (assuming a work week of 40 hours and taking into account the given change in the ratio of the cashier's useful work time):

$$
T N_{w p c}=\frac{O T F-O T F_{r b s}}{O T F_{c}},
$$

where $T N_{w p c}$ is the target number of work places for cashiers;

$O T F$ is the target annual operating time fund;

$R B S$ is the share of transactions going through channels of remote banking service (RBS);

$O T F_{r b s}$ is the target annual operating time fund of remote banking service;

$O T F_{c}$ is the annual operating time fund of one work place for cashiers.

It should be noted that the target annual operating time fund can be divided by channels of remote banking service (RBS) and bank offices in accordance with the target share of remote banking service which has been adopted within the bank for the future.

The calculation of the target number of bank sales offices must be done on the assumption that the bank's office network can be represented by various formats. The credit organization can use its own criteria to determine the necessary number of offices of various format types. For example, one can assume that there should be from 5 to 10 cashiers per office.

The number of self-service devices can be calculated based on the target structure of transactions by channels of remote banking services (RBS) and the normative throughput capacity of the self-service devices of various types. The calculation of the target number can be made in the following way:

$$
\begin{gathered}
T N_{a t m}=\frac{T A T_{r b s} \cdot S_{a t m}}{N T_{a t m}}, \\
T N_{p t}=\frac{T A T_{r b s} \cdot S_{p t}}{N T_{p s}},
\end{gathered}
$$

where $T N_{a t m}$ is the target number of ATMs;

$T N_{p t}$ is the target number of payment terminals;

$T A T_{r b s}$ is the target annual transactions of remote banking service;

$S_{\text {atm }}$ is the share of ATMs in the total volume of transactions carried out by RBS channels;

$N T_{\text {atm }}$ is the normative throughput of ATMs;

$S_{p t}$ is the share of payment terminals in the total number of transactions carried out using RBS channels;

$N T_{p t}$ is the normative throughput of payment terminals.

The calculation of the planned number of sales managers for banking products in an office can be made using the following formula:

$$
N_{s m}=\sum_{m} \frac{N_{s n} \cdot S_{p s} \cdot C_{n s}}{C_{l} \cdot N_{w s} \cdot N S},
$$

where $N_{s m}$ is the number of sales managers;

$N_{s n}$ is the average monthly number of product sales made in a sales office;

$S_{p s}$ is the share of product sales made by sales managers;

$C_{n s}$ is the coefficient of normative sales ' $n$ ' per sales manager per day;

$C_{l}$ is the coefficient of correction taking into account the incompleteness of volume of sales operations given the de facto load. The use of the correction coefficient is necessary in order to take into account auxiliary time, breaks required by the technology and organization of labor, the time for relaxation and personal needs, etc. The value of the coefficient can be determined in detail by a photo of the working time of the sales manager;

$N_{w s}$ is the number of work shifts of the sales manager per month;

$N S$ is the normative of sales per day per sales manager. 


\section{Determination of the habitats of preferred location of offices (stage 2)}

Before proceeding to the determination of the location of points of sale on the local market, it is necessary to perform preliminary work on modeling the habitats of the preferred office locations. For this, one can use specialized software such as ArcGIS ${ }^{1}$. Before starting the modeling, one must determine the boundaries of the city's local markets within which the possibilities of locating sales offices will be evaluated.

A local market is characterized by uniformity, compactness and geographic contiguity. For determination of the boundaries of local markets for bank services, one can take into account the following criteria (Table 3).

In the next step of the given stage, we superimpose the strata of data on the city map. One after another, we set down the following strata of data: location of sales office, population figures (reflecting the density of population by the intensity of filling in this stratum), key generators of customer flow, public transport stops, major shopping centers, the places of existing and promising new legal entity clients (if they are serviced by the sales offices). A source of the data for analysis of the distribution of legal entities in the city is the place of their registration. Such information can be downloaded from the statistics base RUSLANA ${ }^{2}$ (or from any similar database). The potential boundaries of the local market for legal-entity clients of the bank are those obstacles that are hard to overcome such as mainly rivers and railroads with overloaded bridges and crossings. If such obstacles significantly lengthen the route and/ or increase the travel time due to traffic jams, then they must be shown on the map as bound-

\section{Criteria for determining the boundaries of local markets for banking services in a city}

\begin{tabular}{c|c}
\hline Basic criteria & Meaning \\
\hline $\begin{array}{c}\text { Uniformity of type } \\
\text { of construction }\end{array}$ & $\begin{array}{c}\text { Type of district (outlying } \\
\text { residential, city center, mixed, } \\
\text { industrial zone, private sector) }\end{array}$ \\
\hline $\begin{array}{c}\text { No obstacles to free } \\
\text { movement } \\
\text { of pedestrians } \\
\text { Examples of boundaries: } \\
\text { park/forest zones, highways, } \\
\text { railways, waterways, } \\
\text { industrial zones, city border }\end{array}$ \\
$\begin{array}{c}\text { local market into parts } \\
\text { by broad bands of zero } \\
\text { population }\end{array}$ & $\begin{array}{c}\text { Width of a band is greater than } \\
1 \mathrm{~km}\end{array}$ \\
\hline
\end{tabular}

aries separating markets from one another, so that each market services its own client base.

Possible suppliers of information to fill in the respective strata of data are shown in Table 4.

After the strata are set down on the city map, one has to calculate the rasters of densities according to the evaluation maps. A raster is a structure which is a grid of variously colored points which display zones of activity or density. With the help of the rasters, one can understand where there is a cluster of interesting buildings and activities. One can also perform a verification of the accuracy of the data an analysis of the coincidence of the cluster of densities with the real situation in the city.

For clusters of cities with varying populations, we establish a differentiated minimal assessment score: for cities with low population, the minimal score is significantly lower than for large cities.

The potential of a place for a bank office must be evaluated through sales and transaction

\footnotetext{
${ }^{1}$ ArcGIS - a family of geo-information software products from the American company ESRI. They are applied for land cadasters, in the tasks of land development, to account for real estate, systems of utilities, geodesics and subsoil use, as well as in other fields

2 RUSLANA - a database containing information about more than 850,000 Russian companies, as well as around 365,000 companies in the Ukraine
} 
Table 4.

Possible suppliers of information to fill in data on the city map in the process of geomarketing modeling

\begin{tabular}{|c|c|}
\hline Data & Presumptive supplier \\
\hline Sales offices & $\begin{array}{l}\text { Information of the respective } \\
\text { bank subdivision }\end{array}$ \\
\hline Population figures & State statistics bureaus \\
\hline Generators of additional customer flow (shops, restaurants, entertainment centers) & Navteq $^{3}$ \\
\hline Public transport stops & \multirow{3}{*}{$2 \mathrm{GIS}^{4}$} \\
\hline $\begin{array}{l}\text { Major shopping centers, shopping and entertainment complexes, } \\
\text { major food retailers (hypermarkets) }\end{array}$ & \\
\hline Chain-store retailers (supermarkets) & \\
\hline $\begin{array}{l}\text { Data about the registration addresses of legal entities } \\
\text { (in case the sales offices service legal entities) }\end{array}$ & $\begin{array}{c}\text { AMADEUS } 5 / \\
\text { database RUSLANA }\end{array}$ \\
\hline
\end{tabular}

\section{Criteria for the potential of an office location in terms of sales and servicing transactions}

Table 5 .

\begin{tabular}{c|c|c|c|c}
\hline Factor & Criteria & Description & Sales & $\begin{array}{c}\text { Opera- } \\
\text { tions }\end{array}$ \\
\hline Population & $\begin{array}{c}\text { Population numbers within } \\
\text { a radius of } 250 \mathrm{~m}\end{array}$ & $\begin{array}{c}\text { For each } 100 \text { people living in a radius of } 250 \mathrm{~m} ., \\
\text { the sales point get a score of } 1.5 . \text { The stipulated } \\
\text { maximum score for this criterion is } 100\end{array}$ & $10 \%$ & $55 \%$ \\
\hline $\begin{array}{c}\text { Sources of } \\
\text { client flow }\end{array}$ & $\begin{array}{c}\text { Number of sources of client flow } \\
\text { (metro stations, food stores, } \\
\text { restaurants) in a radius of } 250 \mathrm{~m}\end{array}$ & $\begin{array}{c}\text { For each unit source of client flow a score } \\
\text { of } 1.25 \text { is assigned. Maximum score - } 100\end{array}$ & $35 \%$ & $10 \%$ \\
\hline $\begin{array}{c}\text { Transport } \\
\text { stops }\end{array}$ & $\begin{array}{c}\text { Number of public transport } \\
\text { stops in a radius of } 250 \mathrm{~m} .\end{array}$ & $\begin{array}{c}\text { The sum of public transport lines is calculated } \\
\text { for each stop in a radius of } 250 \mathrm{~m} \text {. and for each } \\
\text { unit of this sum the sales point is assigned } \\
\text { a score of 3. Maximum score - } 100\end{array}$ & $15 \%$ & $15 \%$ \\
\hline $\begin{array}{c}\text { Pedestrian } \\
\text { flow }\end{array}$ & $\begin{array}{c}\text { Pedestrian flow in front } \\
\text { of the entrance to the building } \\
\text { of the sales office }\end{array}$ & $\begin{array}{c}\text { For every 10 people passing by the sales office } \\
\text { every 20 minutes on both sides of the street, } \\
\text { the sales point is assigned a score of } 1 . \\
\text { Maximum score - } 100\end{array}$ & $40 \%$ & $20 \%$ \\
\hline
\end{tabular}

${ }^{3}$ Navteq (abbreviation of the English name "Navigation Technologies"; NYSE: NVT) is an American company, world leader in production of digital maps and other data for geo-information systems used in numerous software packages, including navigation systems. In 2012, the company underwent rebranding and it now operates under the HERE brand name

${ }^{4}$ 2GIS is a Russian IT company which produces electronic handbooks bearing the same name with city maps. For each organization in the handbook, they provide the address, telephone number, working hours, internet address and location of the entrance to the building. In addition, the books may contain information specific to the organization's type of activity

${ }^{5}$ AMADEUS is a pan-European database (more than 9 million European companies). For each company in the system, there is a block of general information including contacts, industry affiliation, number of workers and other information, financial accounting for several years, ownership structure and subsidiaries (moreover, this structure is multi-level). The distinguishing feature of this database is how it structures the information 
servicing (with the help of the map of geomarketing evaluation of sales offices). The criteria their description and weighting of sales and operations are shown in Table 5 (weighting shown in the table relates to offices specializing in servicing individuals; their correlation can be corrected based on bank policy and the structure of the organization's portfolio of retail services).

To find the zones of highest activity, the rasters of density are assembled using coefficients from the evaluation map. Data for calculating the coefficients are shown in Table $6(100 \%$ for each evaluation is obtained by adding the value of the pedestrian flow). To obtain the coefficient, one must multiply the assigned score by the necessary percent.

Table 6.

\section{Data for building rasters of density to analyze the potential volumes of sales and operations}

\begin{tabular}{c|c|c} 
Criteria & Sales & Operations \\
\hline $\begin{array}{c}\text { Population } \\
\text { (score of 1.5 per 100 people) }\end{array}$ & $10 \%$ & $55 \%$ \\
\hline $\begin{array}{c}\text { Transport stops } \\
\text { (score 3 per line) }\end{array}$ & $15 \%$ & $15 \%$ \\
\hline $\begin{array}{c}\text { Generators of client flow } \\
\text { (score 1.25 per unit) }\end{array}$ & $35 \%$ & $10 \%$ \\
\hline
\end{tabular}

As we see from Table 6, the coefficients will be different for evaluation of sales and operations. The bank can correct them at its discretion based on its specialization (servicing the population or active sales). The result is two rasters for analysis of potential volumes of sales and operations. After determining the preferred locations of sales offices, the most attractive places on the map are visualized with the help of the map of geomarketing evaluation of the network of sales offices.

On the map of the local market, we place the raster of assessment scores (without taking into account pedestrian flows) separately by criteria of evaluation of the sales potential of transac- tion servicing and we determine the aggregate of places with the highest assessment scores for the given city. At the same time, depending on the result of the 'addition' of two strata, the following situations can arise:

1. Places where there is a coincidence of high scores of potential sales and transaction load (on condition that the distance between geometric centers of the places (habitats) do not exceed 500 meters) are viewed as potential for locating large size sales offices (expanded / flagman or large basic);

2. Places with a high score for sales with relatively low score for transaction load must be seen as potential for locating mini-sales offices;

3. With an inverse correlation between scores, the place can appear to be potentially attractive for locating a basic sales office.

The summary roster obtained in the preceding step is reclassified by 20 quantiles and is color coded. The color range for the raster of sales and transactions is differentiated. As a result, we get a set of habitats ranged by activity and covering around $30 \%$ of the city. These habitats are the preferred locations of sales offices. Initially we examine habitats with predominance of the highest evaluation score (5\%), then preference is given to habitats with less activity.

\section{Determination of the rational coverage of the local market taking into account payback of the sales offices (stage 3)}

After the prospective zones of the organization's presence are determined on the map, it is necessary to perform a search for suitable premises and create the target network of offices. Then comes a search for suitable premises (taking into account the stop factors and the results of payback calculations), which in the future will become elements of the target network of offices for servicing clients in the city. The list of stop factors is shown in Table 7. 
Table 7.

Stop factors influencing the selection of locations for bank offices

\begin{tabular}{c|c|c}
\multicolumn{1}{c|}{ Stop factors } & \multicolumn{2}{c}{ Size of office servicing clients } \\
\cline { 2 - 3 } & Large & Typical \\
\hline Location on the first line of houses next to a thoroughfare/street & Hard factor & Hard factor \\
\hline Location on ground floor of a building & Hard factor & Hard factor \\
\hline No facade windows & Hard factor & Hard factor \\
\hline Height of ceilings in the premises & $3 \mathrm{~m}$. & $2.7 \mathrm{~m}$. \\
\hline Time in transit to nearest office servicing bank clients & 20 minutes & 60 minutes \\
\hline No parking for clients / possibilities to arrange it & Hard factor & Soft factor \\
\hline No possibility to arrange a separate entrance to the area servicing clients & Hard factor & Soft factor \\
\hline
\end{tabular}

As the table shows, all stop factors can be divided into two groups:

४ 'hard' stop factors: locating offices in premises corresponding to at least one of these characteristics is not permissible;

- 'soft' stop factors: locating offices in premises corresponding to such characteristics is allowed, but on condition of justifying such a necessity by the business needs of the organization.

Each place examined for possibly locating a sales office in the local market should be checked for the existence of stop factors. Responsible executives must go out to the site and evaluate the possibility of locating a sales office there. Out of the remaining premises after evaluation of stop factors, one or two are selected, those with the greatest pedestrian flow on both sides of the street immediately in front of the entrance. The intensity of the flow is measured directly, and the value obtained is added to the assessment score of the place. If the calculated full assessment score turns out to be lower than the passing score for all premises examined, then the place is excluded from the list of potential locations for situating a sales office. From the selected places, one builds the ideal network of sales offices for the coming $3-4$ years.

The capacity calculated for the local market by number of work places is next distributed among all the places proportionally to the respective assessment scores. The number of work places for specialists at each office location determines the refined format and overall throughput capacity of the office. On the basis of comparison of current and ideal networks, one builds the plan for development over the coming several years.

Such are the general recommendations for performing modeling for the rational layout of a network of sales offices for a commercial bank. Use of the described methodological approaches to geomarketing modeling enables the commercial bank to solve the task of laying out its offices. At the same time, outside the framework of the project of modeling such an office network there remain questions that are directly linked with the model for managing them. Among these, for example, are the questions on the necessary quantity of office managers, the distribution of responsibility for decision making on closing/opening part of the subdivision, filling out the staffing schedule, recruiting employees, etc. 


\section{Conclusion}

In this way, the practical use of geomarketing modeling enables any bank to achieve rational spatial locations of their offices on local markets where they are present. Applicable to the banking sphere, in a short term perspective geomarketing enables the bank to determine the most preferable layout of offices servicing clients in cities from the point of view of efficiency. In the long term perspective, a credit organization obtains a tool for developing and implement- ing a plan to develop its branch network in the coming years, all of which in the final analysis makes it possible to significantly raise the effectiveness of management decision making as a whole in the bank. The use of tools of geomarketing modeling enables the bank's senior management to effectively use the capacities of its branch network, to react in a timely way to changes in client flows in the city, to achieve greatest effect from managing offices in cities while following its strategic plans.

\section{References}

1. Soenen L.A. (1974) Locating bank branches. Industrial Marketing Management, no. 3 (21), pp. 211-228.

2. Tsvetkov V.Y. (2002) Geomarketing: prikladnye zadachi i metody [Geomarketing: Applied tasks and methods]. Moscow: Finance and Statistics (in Russian).

3. Zhurkin I.G., Tsvetkov V.Y. (1998) GIS i geomarketing [GIS and geomarketing]. Izvestiya Vuzov. Geodesy and aerophotography, no. 3, pp. 146-150 (in Russian).

4. Bakaeva V.V., Kurushina N.V. (2011) Podkhody k optimizatsii razmeshcheniya predpriyatiy roznichnoy torgovli [Approaches to optimization of retail enterprises location]. Russian Entrepreneurship, no 6-2, pp. 160-166 (in Russian).

5. Bell R.R., Zabriskie N.B. (1978) Assisting marketing decisions by computer mapping: A branch banking application. Journal of Marketing Research, no. 15 (1), pp. 122-128.

6. Kiselgof S.G. (2011) Modeli restrukturizatsii filial'noy seti kommercheskogo banka [Models of restructuring of a commercial bank's branch network]. Proceedings of XI International Academic Conference on Economic and Social Development. Moscow, 6-8 April 2010. Vol. 1 (ed. E.G. Yasin). Moscow: HSE, pp. 594-605 (in Russian).

7. Boufounou P.V. (1995) Evaluating bank branch location and performance: A case study. European Journal of Operational Research, no. 87, pp. 389-402.

8. Huff L.D. (1964) Defining and estimating a trading area. Journal of Marketing, no. 28, pp. 34-38.

9. Berman O. (1997) Deterministic flow-demand location problems. Journal of the Operational Research Society, vol. 48, no. 1, pp. 75-81.

10. Craig S.C., Ghosh A. (1983) Formulating retail location strategy in a changing environment. Journal of Marketing, vol. 47, no. 3, pp. 56-68.

11. Ioannou G., Mavri M. (2007) Performance-net: Decision support system for reconfiguring a bank's branch network. International Journal of Management Science, no. 35 (2), pp. 190-201.

12. Min H.A. (1989) Model-based decision support system for locating banks. Information and Management, no. 17 , pp. 207-215.

13. Aleskerov F.T., Belousova V.Y. (2007) Effektivnoe razvitie filial'noy seti kommercheskogo banka [Efficient development of a commercial bank's branch network]. Management in a Credit Institution, no. 6, pp. 23-34 (in Russian).

14. Aleskerov F.T., Belousova V.Y. (2007) Otsenka privlekatel'nosti regionov RF dlya razvitiya filial'noy seti kommercheskogo banka [Evaluating attractiveness of RF regions for development of a commercial bank's branch network]. Banking Business, no. 8, pp. 54-57 (in Russian).

15. Kiselgof S.G., Aleskerov F.T. (2009) Razmeshchenie otdeleniy banka. Obzor problemy [Location of a bank's branches. Overview of the problem]. Business Informatics, no. 1 (07), pp. 59-69 (in Russian). 